
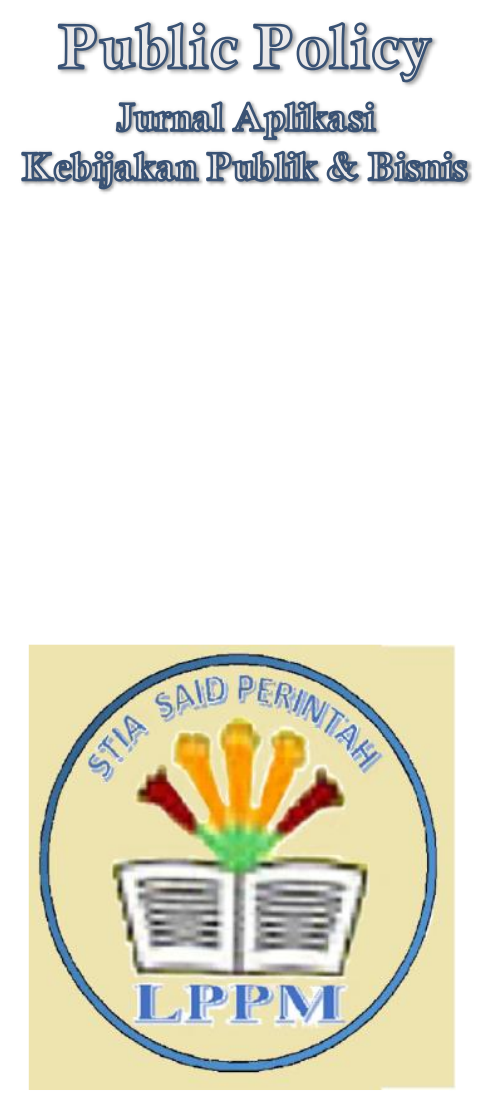

LPPM STIA Said Perintah

Volume 2, No. 1, Maret 2021

https://stia-saidperintah.e-journal.id/ppj

\section{Perangkat Pembelajaran Usaha dan Energi Berbasis STEM Terintegrasi Kearifan Lokal Timba Laor di Negeri Allang Kabupaten Maluku Tengah}

\author{
Anatasija Limba ${ }^{1}$ \\ Clara Levenia Jamarua ${ }^{2}$
}

\author{
1,2Prodi Pendidikan Fisika FKIP Universitas Pattimura \\ anatasijalimba508@gmail.com
}

\begin{abstract}
21st-century learning should include STEM to grow interested in the Indonesian nation to love and master science, technology, engineering, and mathematics. They are included in it for physics learning. STEM is a practical learning approach because it combines knowledge, mathematics, technology, and techniques. This aim to make students as problem-solvers, inventors, have innovation, independent logical thinking, technological literacy, connect their culture and history with education, and apply their knowledge in real life. Thus, it is necessary to implement STEM-based learning integrated lokal wisdom /culture of the community in which the learners are located. One of the lokal wisdom of coastal communities in Maluku is Timba Laor. This research aims to develop a High School Physics Learning Tool business concept, and STEM-based Energy integrated lokal wisdom Timba Laor in the village of Allang Central Maluku district, a valid, practical, and effective Plomp model. The stages of mining carried out in this research activity are the development of high school physics learning tools business concept and STEM-based Energy integrated lokal wisdom Timba Laor in the village of Allang Central Maluku District. Test models by providing surveys of physics teachers to empirically validate the learning devices that have been compiled, analyzed, and revised. The resulting product is a learning device physics high school concept business, and energy-based STEM integrated lokal wisdom.

Keywords : Business and Energy, Learning Tools, STEM, Timba Laor
\end{abstract}




\section{Pendahuluan}

Masa abad 21 mewajibkan seluruh susunan warga Indonesia menggemari dan menerapkan hasil teknologi. Realitasnya, pemahaman tentang IPTEK oleh masyarakat masih banyak yang tidak ingin menekuni ataupun kurang berminat. Upaya minimum telah dicoba dengan memasukkan aspek sains, tecknologi, teknik, dan matematika dalam pendidikan di sekolah untuk mengembangkan perhatian generasi muda Indonesia untuk menikmati dan memahami ilmu pengetahuan, teknologi, teknik dan matematika (Kaniawati, 2019). Menurut Octavia, (2017), bahwa pendekatan pendidikan saat ini adalah pendidikan berdasarkan sains, teknologi, teknik, dan matematika yang sangat mendukung pencapaian kompetisi abad ke-21. Pendidikan STEM berfokus pada pendidikan yang melibatkan empat bidang disiplin ilmu. Hal ini disebabkan oleh ilmu pengetahuan alam, teknologi, rekayasa, dan matematika adalah dasar dalam pertumbuhan sains dan teknologi (IPTEKS). Secara universal tujuan pendidikan berbasis STEM ialah mempraktekkan konten dasar dari STEM dalam konteks kehidupan yang nyata sehingga siswa melek STEM (Bybee, 2013). STEM adalah metode pembelajaran pendidikan yang berbasis pada penerapan ilmu pengetahuan, matematika, teknologi, dan matematika (Sukmana, 2018).

Menurut Marrison, (2006), salah satu tujuan pendidikan STEM agar siswa terbentuk menjadi problem solver, penemu, inovasi, independen, berpikir logis, dan literasi teknologi serta mampu menghubungkan antara sejarah budaya, pendidikan dan pengetahuannya yang diterapkan dalam kehidupan nyata. Berdasarkan hal tersebut maka implementasi pembelajaran berbasis STEM terintegrasi kearifan lokal/budaya masyarakat perlu digalakkan di lingkungan dimana peserta didik tinggal. Ibrahim, (2014) mengatakan bahwa integrasi kearifan lokal dalam aktifitas pendidikan dan pembelajaran sangat potensial untuk dimunculkan sebagai suatu inovasi atau kebaharuan. Namun pada kenyataannya, belum semua Lembaga Pendidikan menerapkan pembelajaran STEM yang terintegrasi kearifan lokal, khususnya dalam pembelajaran Fisika di Maluku. Para peserta didik belum memanfaatkan sepenuhnya alternatif pembelajaran sains dan teknologi untuk merancang pendidikan yang lebih menarik dan bermakna. Mengaitkan budaya kearifan lokal di wilayah dimana siswa tersebut tinggal lebih dipahami sebagai kekayaan nasional yang dapat dipromosikan secara nasional atau internasional (Utami et al., 2017). 
Menurut Oktavianti \& Ratnasari, (2018), penerapan pendidikan di Indonesia menggunakan pembelajaran berbasis kearifan lokal bertujuan agar peserta didik mampu menjaga dan melestarikan nilai-nilai kearifan lokal. Kearifan lokal dalam masyarakat dapat berupa budaya (nilai, norma, etika, kepercayaan, adat istiadat, hukum adat, dan aturan-aturan khusus). Untuk mengidentifikasi hal ini maka adaptasi terhadap STEM harus diterapkan disesuaikan dengan informasi sains melalui pengembangan kualitas berpikir logis berbasis kearifan lokal setempat (Suastra, 2010). Pembelajaran yang menyeimbangkan pengetahuan Fisika melalui penanaman nilai-nilai ilmiah dan kearifan lokal akan terwujud jika perangkat pembelajaran disusun dan diterapkan dengan baik sehingga dapat menentukan keberhasilan siswa dalam kegiatan belajar mengajar.

Belajar dengan perangkat pembelajaran adalah indera atau peralatan bagi seorang guru. Keberhasilan guru dalam pembelajaran dapat dicapai melalui penggunaan perangkat pembelajaran yang optimal. Seorang guru dapat dibantu melalui penggunaan pedoman perangkat pembelajaran untuk meningkatkan dan mengembangkan teknik pengajarannya (Nuraini, Tindangen, M., \& Maasawet, 2016). Beberapa komponen perangkat pembelajaran dapat digunakan untuk mencapai keberhasilan tujuan pembelajaran. Salah satu diantaranya melalui pemanfaatan perangkat pembelajaran. Seorang pendidik akan sulit ditingkatkan efektivitas pembelajarannya jika tidak didukung dengan perangkat pembelajaran yang memadai(Hartini et al., 2017). Dengan demikian, dari hasil review terhadap kajian teori dan hasil-hasil penelitian relevan tentang pembelajaran Fisika berbasis STEM terintegrasi kearifan lokal di Kabupaten Maluku Tengah belum pernah dilakukan. Bertolak dari hal tersebut, maka permasalahan utama dalam penelitian ini adalah bagaimana mengembangkan perangkat pembelajaran usaha dan energi berbasis STEM terintegrasi kearifan lokal Timba Laor di Negeri Allang, Kecamatan Leihitu Barat Kabupaten Maluku Tengah?

\section{Kajian Teoritis}

\section{Perangkat Pembelajaran}

Menurut Akbar, (2013), bahwa perangkat pembelajaran adalah berbagai materi, perangkat, media, arahan, dan aturan yang akan digunakan dalam siklus pembelajaran di kelas. Siklus menginstruksikan belajar dapat terjadi dengan tepat setiap kali guru dan siswa menggunakan perangkat pembelajaran. 
Beberapa sudut pandang yang dijadikan motivasi mengapa perangkat pembelajaran penting dalam siklus pembelajaran meliputi: 1) menjadi panduan; instrumen pembelajaran digunakan sebagai panduan bagi pendidik untuk mengevaluasi apa yang perlu dilakukan individu yang bersangkutan di ruang belajar. Panduan ini dimanfaatkan oleh Guru untuk membuat strategi mengajar dan merencanakan tools yang lebih baik; 2) instrumen pembelajaran sebagai tolok ukur: untuk mengetahui tingkat alat pembelajaran yang digunakan oleh Guru dan merencanakan aplikasi untuk menilai dirinya di kelas dan diandalkan untuk sebagai pilihan untuk meningkatkan keterampilan yang dapat diperagakan dari seorang guru; 3) Perangkat pembelajaran dapat meningkatkan profesionalisme, metodologi dari pendidik dapat ditingkatkan dengan penyempurnaan perangkat pembelajaran. Hal Ini menyiratkan bahwa instrumen pembelajaran adalah sebagai pemenuhan kebutuhan manajerial, tetapi sebaliknya digunakan untuk memperbaiki cara dan metodologi mengajar; 4) Perangkat pembelajaran dibuat lebih sederhana: memiliki alat pembelajaran sederhana Guru dan Siswa dapat terbantu dan didorong berinteraksi pembelajaran. Melalui perangkat pembelajaran Guru tidak diragukan lagi dapat menyampaikan materi hanya dengan menyediakan perangkat tanpa harus berpikir dan mengingat.

Komponen-komponen perangkat pembelajaran yang digunakan dalam penulisan ini terdiri dari Analisis $S K L-K I / K D$, silabus, RPP, LKPD dan penilaian. Komponen-komponen ini saling berkaitan dan tidak dapat dipisahkan satu dengan yang lainnya. Perangkat pembelajaran ini diharapkan dapat dikembangkan dengan baik agar menjadikan pembelajaran di kelas lebih efektif.

\section{Science, Tecknology, Engineering, and Mathematic (STEM)}

Terminologi STEM pertama kali digunakan oleh NSF (National Science Foundation) pada tahun 1990-an yang merupakan akronim dari kata Science, Engineering, Technology, dan Mathematics. Ilmu pengetahuan dan teknologi biasanya digunakan untuk mempelajari alam semesta, fakta-fakta, fenomena, dan keteraturan didalamnya. Teknologi ialah perubahan inovasi maupun modifikasi terhadap lingkungan alam untuk memberi kepuasan terhadap keinginan dan kebutuhan manusia (International Technology Education Association, 2000).

Teknologi bertujuan untuk membuat modifikasi pada dunia ilmu pengetahuan dan teknologi dalam memenuhi kebutuhan manusia (National Committee on Science Education Standard, 1996). Lebih lanjut dapat dikatakan bahwa makna teknologi lebih 
luas diartikan sebagai peningkatan kemampuan manusia untuk mengubah dunia dengan cara memotong, membuat, dan menyatukan material-material serta memindahkan sesuatu dari satu lokasi ke lokasi lain. Technology (teknologi) dibentuk untuk mencapai sesuatu yang lebih hebat dengan bantuan tangan, bunyi, dan perasaan. Engineering (rekayasa) adalah sebuah profesi untuk memperoleh pengetahuan sains dan matematika yang dilakukan melalui studi, eksperimen, dan praktek serta mampu diaplikasikan dengan mempertimbangkan aspek metafisik dalam pengembangan bahan-bahan dan kekuatan alam untuk kebutuhan manusia. Mathematics ialah cabang disiplin ilmu yang digunakan dalam mengkaji berbagai macam pola maupun hubungan yang terjadi dialam (AAAS, 1993).

Bila ditinjau asal sudut pandang maka STEM bukanlah hanya sebuah jargon/akronim tetapi memiliki suatu tujuan dan pencapaian dalam dunia pendidikan. Pendidikan STEM bertujuan supaya semua peserta didik mampu menerapkan dan mempraktekkan konten dasar STEM sesuai situasi yang mereka hadapi/temukan didalam kehidupan supaya menjadi melek STEM (STEM literacy) (Bybee, 2013).

Acuan dari melek STEM lain: 1) seseorang individu memiliki pengetahuan, perilaku, dan keterampilan dalam mengidentifikasi sejumlah pertanyaan dan permasalahan kehidupan nyata dan mengungkapkannya secara alamiah dan terancang (natural and design world), serta menggambarkan simpulan berbasis berita maupun informasi terkait isu-isu terkini pembelajaran STEM. Seorang individu memerlukan pemahaman tentang karakteristik disiplin ilmu STEM yang dibentuk melalui pengetahuan, inkuiri, dan desain manusia; 2) seorang individu memiliki pengetahuan tentang bagaimana STEM dibentuk dari material, intelektual, dan budaya lingkungan, dan 3) seorang individu diharapkan untuk merangkaikan pengetahuan dengan informasi STEM dan menggunakan inspirasi/pandangan baru tentang science, technology, engineering, dan mathematics sebagai masyarakat yang konstruktif, peduli, dan reflektif.

Program pendidikan STEM dinilai perlu diintegrasikan berdasarkan kecakapan dan keterampilan yang harus dimiliki oleh siswa sesuai dengan standar (NRC, 2010). Keterampilan yang harus dimiliki adalah sebagai berikut: 1) Adaptability (kecakapan untuk beradaptasi terhadap suatu kondisi yang tidak umum); 2) Complex communication skills (keterampilan dalam memproses dan menginterpretasi informasi baik secara verbal maupun non verbal). 3) Non-routine problem solving (kemampuan dalam menyelesaikan 
masalah yang tidak umum). 4) Self management and self development (kecakapan untuk bekerja dalam kelompok maupun sendiri secara otomatis); System thinking (kecakapan untuk memahami kerja seluruh sistem bagaimana pengaruhnya dari suatu tindakan perubahan terhadap sistem).

\section{Kearifan Lokal}

Kearifan lokal (lokal wisdom) merupakan bagian dari budaya suatu warga yang tidak dapat dipisahkan dari bahasa rakyat itu sendiri. Kearifan lokal umumnya diwariskan secara turun temurun dari satu generasi ke generasi melalui cerita dari ekspresi ke verbal. Kearifan lokal terdapat pada cerita warga, peribahasa, lagu, dan permainan warga. Kearifan lokal sebagai suatu pengetahuan yang ditemukan oleh warga lokal tertentu melalui deretan pengalaman dalam mencoba yang diintegrasikan memakai pemahaman terhadap budaya serta keadaan alam suatu kawasan (Baedowi, 2015). Pendapat lain mengungkapkan bahwa kearifan lokal adalah pandangan hidup dan ilmu pengetahuan serta aneka macam seni manajemen kehidupan yang diwujudkan melalui aktivitas masyarakat lokal untuk menjawab berbagai problematika pemenuhan kebutuhan. Dalam bahasa asing seringkali pula dikonsepsikan menjadi pengetahuan setempat/lokal atau eksistensi setempat.

Menurut Zulkarnain \& Febriamansyah, (2008), terminology kearifan lokal berasal dari pandangan budaya bisa dicermati menjadi pengetahuan lokal dari budaya warga, unik, memiliki hubungan menggunakan alam berdasarkan sejarah yang panjang, mengikuti keadaan menggunakan sistem ekologi setempat, bersifat dinamis dan selalu terbuka terhadap pengetahuan baru. Mukti, (2010), menyatakan bahwa secara khusus kearifan lokal dapat diartikan sebagai suatu pengetahuan lokal, unik yang asal berasal budaya warga setempat dapat dj̈adikan dasar pengambilan keputusan pada di tingkat lokal pada bidang pertanian, kesehatan, penyediaan kuliner, pendidikan, pengelolaan sumberdaya alam, dan beragam aktivitas lainnya pada komunitas-komunitas.

Kearifan lokal merupakan suatu pola kebiasaan yang terjadi secara terus menerus dalam jangka waktu yang relatif lama. Dengan demikian bisa diartikan bahwa kearifan lokal memiliki keeratan hubungan dengan kebudayaan. Menurut Taylor, (2019), bahwa kebudayaan adalah keseluruhan aspek budaya yang mencakup pengetahuan, kepercayaan, kesenian, moral, aturan, adat istiadat, dan norma-norma serta kemampuan-kemampuan lainnya pada manusia yang diperoleh sebagai anggota masyarakat. Berdasarkan beberapa definisi tersebut maka bisa disimpulkan bahwa 
kearifan lokal ialah gagasan yang muncul dan berkembang disuatu wilayah dikenal sebagai norma adat, tata hukum/adat, nilai, budaya, kepercayaan, dan norma kehidupan sehari-hari. Penerapan kearifan lokal dalam proses pembelajaran Fisika bertujuan untuk meningkatkan penguasaan konsep peserta didik dengan menggali dan mencari informasi keadaan lingkungan fisik atau norma-norma yang ada pada kehidupan sehari-hari sehingga dapat diaplikasikan dalam kelas pembelajaran Fisika. Hal mempengaruhi peserta didik dalam mengingat dan memahami materi pembelajaran karena konsep ini sering dialami oleh peserta didik itu.

Provinsi Maluku terdiri dari 11 Kabupaten/Kota termasuk dalam wilayah 3T (terdepan, terluar, dan tertinggal dimana sebagian besar penduduk mendiami pulau besar dan kecil yang dipisahkan oleh laut dan selat. Laut pulau merupakan sebuah konsep pengembangan kepulauan yang terintegrasi dan sebagai perpaduan laut dan pulau-pulau maupun wilayah sekitarnya menjadi satu kesatuan utuh termasuk didalamnya potensi sumberdaya alam dan manusia penghuni pulau. Provinsi ini terbagi menjadi 9 kabupaten dan 2 kota dan terdapat 118 kecamatan yang terdiri dari 35 kelurahan dan 1.198 desa maupun negeri. Jumlah penduduk terbesar berada di ibukota provinsi Kota Ambon, sedangkan wilayah terluas yaitu Kabupaten Maluku Tengah (Badan Pusat Statistik Provinsi Maluku, 2021). Tuhulele, (2009), mengatakan bahwa provinsi Maluku merupakan salah satu provinsi yang secara geografis memiliki wilayah laut lebih luas dibandingkan dengan daratan, serta jumlah pulau mencapai 976 buah. Penduduk Maluku sebagaian besar menempati wilayah pesisir pada pulau besar maupun kecil. Adanya persebaran penduduk pada wilayah pesisir menunjukkan bahwa masyarakat ini memiliki keragaman kearifan lokal. Masing-masing gugus pulau-pulau ini memiliki ciri khas tersendiri yang telah diwariskan secara turun temurun. Kearifan lokal yang dimiliki oleh penduduk setempat dapat memberikan inspirasi bagi pengayaan dan pengembangan bahan ajar Fisika. Nilai-nilai tradisional dalam budaya lokal ini perlu dilestarikan dan digunakan dalam pengembangan bahan ajar mata ajaran Fisika. Hal ini selaras dengan visi dari Universitas Pattimura untuk menjadi Pusat Pengembangan Sumberdaya Manusia, Ilmu pengetahuan, Teknologi, dan Seni yang Unggul, Berkarakter, Berbudaya, dan Berbasis laut pulau.

Salah satu budaya kearifan lokal pada masyarakat di wilayah pesisir di Maluku yang terus menerus dilestarikan adalah tradisi Timba Laor. Tradisi Timba Laor masih dipertahankan oleh warga Negeri Allang sebagai salah satu pola hidup sehari-hari yang 
telah diwariskan secara secara turun termurun dari generasi ke generasi. Arti dari Timba Laor merupakan kegiatan manusia untuk menangkap cacing laut. Tradisi ini merupakan berkat alam yang luar biasa bagi warga Negeri Allang dan telah dikenal sejak ratusan tahun lalu yang terus dilestarikan sampai saat ini. "Laor" adalah sejenis cacing laut dalam bahasa ilmiahnya Lycde oele termasuk dalam kelas Polychaeta, Filum Anelida. Hewan ini biasanya muncul saat terjadi purnama pasang tertinggi pada daerah pantai yang berkarang. Laor adalah salah satu hewan alternatif yang secara turun temurun sangat diminati oleh warga Negeri Allang. Hal ini disebabkan oleh gizi protein hewan tersebut yang tinggi sehingga oleh masyarakat setempat dipercaya sebagai makanan bergizi. Hewan ini muncul diduga disebabkan oleh adanya dorongan pasang surut air laut dan kadar garam. Hewan ini biasanya melakukan proses reproduksi dipengaruh oleh transisi perubahan musim panas (barat) ke musim hujan (timur). Proses ini biasanya terjadi pada bulan Maret atau April. Sebelum munculnya binatang ini, merupakan hari terpanas dalam satu tahun. Kejadian ini dijuluki oleh penduduk lokal sebagai panas Laor. Sedangkan malam hari saat cuaca panas terjadi panas Laor berlangsung selama 3 hari setelah bulan purnama.

\section{Metode Penelitian}

Penelitian ini ialah pada jenis penelitian dan pengembangan model. Model pengembangan penelitian ini merujuk pada model pengembangan pendidikan berdasarkan Plomp, (1997). Secara garis besar model ini dikelompokkan atas 3 tahapan besar. Tahapan-tahapan ini diuraikan sebagai berikut: 1) pengembangan perangkat pembelajaran Fisika SMA berbasis STEM terintegrasi kearifan lokal Kabupaten Maluku Tengah; 2) Uji model melalui survei terhadap guru-guru Fisika untuk memvalidasi secara empirik perangkat pembelajaran yang telah disusun, dianalisis, dan direvisi. Penelitian ini dilaksanakan di Negeri Allang, kecamatan Leihitu Barat Kabupaten Maluku Tengah, berlangsung selama 2 tahun. Tahun pertama, dilakukan uji coba subjek terbatas terhadap 8 orang guru Fisika SMA di Kabupaten Maluku Tengah. Data dikumpulkan dengan menggunakan: (a) lembar pengamatan kearifan lokal; (b) format keterkaitan STEM dengan kearifan lokal serta kaitannya dengan konsep Fisika SMA; (c) kuesioner untuk guru, berisikan pertanyaan atau pernyataan berkaitan dengan evaluasi diri terhadap penggunaan perangkat pembelajaran Fisika; (d) lembar penilaian perangkat pembelajaran; dan (e) kuesioner untuk validasi empirik perangkat pembelajaran yang 
telah disusun terhadap. Perangkat-perangkat ini sebelum digunakan terlebih divalidasi dahulu oleh pakar (ahli). Analisis data hasil penelitian menggunakan statistik deskriptif kualitatif.

\section{Hasil dan Pembahasan}

Setiap kegiatan penelitian, uraian hasil dan pembahasan disesuaikan dengan langkah-langkah penelitian yaitu Preliminary investigation; 2) Design; 3) Realiazation/construction; 4) Test, evaluation, and revision. Tahap awal kegiatan adalah mengumpulkan data dan informasi terkait kearifan lokal Timba Laor di Negeri Allang, analisis keterkaitan antara kearifan lokal penduduk setempat dengan konsep Fisika, dan pemanfaatan kearifan lokal dalam pembelajaran Fisika berbasis STEM. Teknik pengambilan data dilakukan melalui observasi, wawancara mendalam dan kajian artikel tentang kearifan lokal masyarakat setempat. Hasil observasi dan wawancara selanjutnya oleh Tim dan masyarakat setempat didiskusikan bersama dalam bentuk focus grup untuk menentukan keterkaitan antara kearifan lokal dengan konsep pembelajaran Fisika berbasis STEM. Konsep pembelajaran Fisika yang digunakan berhubungan dengan kearifan lokal Timba Laor adalah konsep usaha dan energi (SMA Kelas X). Observasidan wawancara khusus terhadap guru mata pelajaran Fisika juga telah dilaksanakan pada salah satu SMA di Kecamatan Leihitu Barat terkait dengan topik penelitian ini.

Hasil penelitian menunjukkan bahwa sebagian besar pendidik tidak pernah menggunakan kearifan dalam pembelajaran ilmu Fisika berbasis STEM. Hal ini dikarenakan tidak adanya informasi dari pendidik ini tentang pemanfaatan budaya kearifan lokal yang dapat dilaksanakan dalam pembelajaran. Instruktur juga merasa tertarik dan bersedia memanfaatkan materi ini dalam siklus pembelajaran karena hal ini oleh siswa di lingkungan tempat tinggalnya. Cara ini sangat baik karena budaya kearifan lokal dapat dimanfaatkan sebagai sumber pembelajaran. Seorang pendidik harus memiliki pilihan untuk membuat jenis materi pembelajaran yang menarik sehingga siswa tertarik untuk mempelajari dan ada peningkatan dalam pembelajaran (Rahmayanti, Wati, dan Mastung, 2017).

Inovasipembelajaran Fisika semakin menarik jika materi yang diajarkan sebagai sarana sumber belajar terkait dengan aktivitas sehari-hari pebelajar. Peserta didik difasilitasi dalam pembelajaran Fisika oleh guru melalui pemanfaatan sumber-sumber belajar yang berhubungan dengan kearifan lokal penduduk setempat. Selanjutnya dari 
hasil investigasi awal ini akan djadikan sebagai dasar untuk merancang tahap awal pembuatan desain perangkat pembelajaran Fisika konsep Usaha dan Energi berbasis STEM terintegrasi kearifan lokal Timba Laor. Kegiatan yang telah dilakukan adalah merancang perangkat pembelajaran melalui analisis Standar Kompetensi Lulusan (SKL), mengembangkan Silabus, mengembangkan RPP, dan mengembangkan LKPD.

Tahapan desain (design) merupakan kegiatan lanjutan pada tahap perancangan. Pada tahap ini dihasilkan prototipe 1 (awal) sebagai realisasi hasil perancangan perangkat pembelajaran Fisika konsep Usaha dan Energi berbasis STEM terintegrasi kearifan lokal Timba Laor. Tahapan fase-fase yang dilakukan dalam kegiatan ini meliputi:

1. Menyusun konsep Fisika terkait dengan kearifan lokal untuk digunakan dalam analisis SKL.

2. Membagi kearifan lokal sesuai dengan IPK pada konsep yang diajarkan dan disesuaikan juga dengan sintaks/langkah-langkah pembelajaran berbasis STEM.

3. Mengembangkan perangkat pembelajaran Fisika konsep Usaha dan Energi berbasis STEM terintegrasi kearifan lokal Timba Laor. Perangkat pembelajaran ini selanjutnya dirancang sesuai desain yang sudah dibuat pada tahap perencanaan.

Model perangkat pembelajaran ini dikonstruksi dan diteliti kembali apakah sudah memenuhi kecukupan teori-teori pendukung model dan telah diterapkan dengan baik pada setiap komponen-komponen model yang siap diuji validasi oleh para ahli dan praktisi berdasarkan sudut rasional teoritis serta kekonsistenan konstruksi. Pada tahap ini, didapatkan prototipe 1 sebagai bagian terintegrasi. Contoh prototipe 1 , yakni realisasi hasil perancangan pembelajaran Fisika konsep usaha dan energi berbasis STEM terintegrasi kearifan lokal Timba Laor di Negeri Allang, kecamatan Leihitu Barat, Kabupaten Maluku Tengah. Hasil-hasil konstruksi ini diteliti kembali apakah perangkat pembelajaran telah memperlihatkan secara operasional sintaks pembelajaran STEM, apakah teori-teori pendukung telah diterapkan dengan baik, dan apakah siswa difasilitasi pembelajarannya dengan mengkonstruksi pengetahuan dan keterampilan berbasis kearifan lokal. Jika hal ini sudah bisa terjawab maka langkah berikutnya adalah melakukan uji validasi perangkat pembelajaran, rasionalitas, teoritis, dan kekonsistenan konstruksinya oleh para pakar maupun praktisi.

Pada tahapan test, evaluation, and revision; ada 2 kegiatan utama yang dilakukan antara lain: a) kegiatan validasi oleh pakar terkait konten Fisika dan 
pembelajaran; (b) melakukan ujicoba lapangan prototipe model hasil validasi. Kegiatan validasi ini dilakukan memakailembar validasi yang sudah divalidasi terlebih dahulu oleh para pakar untuk menguji kelayakan instrumen-instrumen tersebut untuk mengukur aspek-aspek yang telah ditetapkan, ditinjau dari kejelasan tujuan pengukuran yang dirumuskan, kesesuaian butir-butir pertanyaan setiap aspek, penggunaan bahasa, dan kejelasan petunjuk penggunaan instrumen.

Kegiatan validasi isi dan konstruksi model dilakukan oleh tim pakar dan praktisi terhadap perangkat pembelajaran maupun instrumen. Para ahli bertindak sebagai validator konten Fisika dan pendidikan Fisika, sedangkan guru Fisika bertindak sebagai praktisi. Validasi perlu dilakukan untuk meminta pertimbangan ahli dan praktisi tentang kelayakan draft perangkat pembelajaran (prototipe 1) yang telah direalisasikan. Hasil validasi yang telah disarankan oleh pakar dan praktisi digunakan sebagai landasan penyempurnaan atau revisi model. Hasil validasi yang dilakukan oleh ke (8) delapan validator bersifat valid dengan sedikit revisi. Saran dan masukkan yang diusulkan oleh para validator terkait operasional sintaks dan produk STEM dalam RPP dan LKPD maupun tampilan gambar-gambar. Validator menyarankan untuk mengaitkan kejelasan antara gambar-gambar dan keterkaitan peristiwa kearifan lokal dengan konsep Fisika Usaha dan Energi. Selanjutnya setelah dilakukan revisi atas masukkan dari para validator untuk menyempurnakan perangkat pembelajaran. Dari hasil revisi perangkat pembelajaran dan validasi akhir merupakan produk penelitian tahun pertama yang siap diujicobakan pada tahun kedua.

\section{Kesimpulan}

Perangkat pembelajaran Fisika SMA konsep Usaha dan Energi berbasis STEM terintegrasi kearifan lokal Timba Laor di desa Allang Kabupaten Maluku Tengah hasil analisis dan revisi uji empirik dapat digunakan untuk uji coba skala kecil dan skala luas untuk menghasilkan produk hasil pengembangan.

\section{Daftar Pustaka}

AAAS. (1993). Benchmarks for science literacy. Oxford University Press.

Akbar, S. (2013). Instrumen Perangkat Pembelajaran. Rosdakarya.

Badan Pusat Statistik. (2021). Statistik Provinsi Maluku 2021. In Statistik Provinsi Maluku. BPS Provinsi Maluku. file://C:/Users/CHRISLEIWA/Downloads/Documents/Provinsi 
Maluku Dalam Angka 2021.pdf

Baedowi, A. (2015). Calak Edu 4: Esai-esai Pendidikan 2012-2014. Pustaka Alvabet. https://books.google.co.id/books?id=gDSLCWAAQBAJ

Bybee, R. (2013). STEM education challenges and opportunities. Virginia: NSTA Press. Hartini, S., Misbah, Helda, \& Dewantara, D. (2017). The effectiveness of physics learning material based on South Kalimantan lokal wisdom. AIP Conference Proceedings, 1868. https://doi.org/10.1063/1.4995182

Ibrahim, M. (2014). Inovasi Pembelajaran Sains Berbasis Kearifan Lokal. In S. N. "Sains dan I. P. B. K. Lokal" (Ed.), Inovasi Pembelajaran Sains Berbasis Kearifan Lokal. IKIP Mataram.

International Technology Education Association. (2000). STANDARDS FOR TECHNOLOGICAL LITERACY: Content for the Study of Technology (p. 9).

Kaniawati. (2019). Implementasi Pembelajaran Fisika Berbasis STEM dalam Meningkatkan Kemampuan Abad 21.

Marrison, J. . (2006). Attributes of STEM education: The students, the academy, the classroom.

Mukti, A. (2010). Beberapa Kearifan Lokal Suku Dayak Dalam Pengelolaan Sumberdaya Alam (p. 1). Brawijaya.

National Committee on Science Education Standard. (1996). National Science Education Standards. NAT I O NAL ACADEMY PRESS.

NRC. (2010). National Science Education Standard. Academic Press.

Octavia, R. (2017). Bahan Ajar Berbasis Science, Technology, Engineering, Mathematics (Stem) untuk Mendukung Pembelajaran IPA Terpadu. Jurnal Semesta Pendidikan IPA, 32-36.

Plomp, T. (1997). Educational and Training System Design. Twente University.

Rahmayanti, P. ., Wati, M., \& Mastuang. (2017). Pengembangan Modul Suhu dan Kalor Menggunakan Model Pembelajaran Kooperatif Tipe Somatic, Auditory, Visual, and Intellegent (SAVI) untuk Siswa Kelas X SMA Negeri 7 Banjarmasin. Berkala Ilmiah Fisika, 4(3).

Ratnasari, I., \& Oktavianti, Y. (2018). Etnopedagogi dalam Pembelajaran di Sekolah Dasar Melalui Media Berbasis Kearifan Lokal. Refleksi Edukatika: Jurnal Ilmiah Kependidikan, 8(2). https://doi.org/10.24176/re.v8i2.2353

Suastra, I. W. (2010). Model pembelajaran sains berbasis budaya lokal untuk 
mengembangkan kompetensi dasar sains dan nilai kearifan lokal di SMP 43(1). Jurnal Pendidikan Dan Pengajaran, 43(1).

Sukmana, W. . (2018). PENDEKATAN SCIENCE, TECHNOLOGY, ENGINEERING AND MATHEMATICS (STEM) SEBAGAI ALTERNATIF DALAM MENGEMBANGKAN MINAT BELAJAR PESERTA DIDIK SEKOLAH DASAR. Pendas: Jurnal Ilmiah Pendidikan Dasar, 2(2), 189. https://doi.org/10.23969/jp.v2i2.798

Taylor, E. . (2019). Religion and Culture (L. T. S. Paul-François Tremlett, Graham Harvey (ed.)). Bloomsbury Academic.

Tuhulele, P. (2009). Pembakuan Nama Pulau Indonesia Upaya Mempertahankan Konsep Negara dan Kepulauan. Gajah Mada.

Utami, I. ., Firman, R., Septiyanto, Catur, F., Wibowo, \& Suryana, A. (2017). Pengembangan STEM-A (Science, Technology, Engineering, Mathematic and Animation) Berbasis Kearifan Lokal dalam Pembelajaran Fisika. 6(1), 67-73. https://doi.org/10.24042/jpifalbiruni.v6i1.1581

Zulkarnain, A. A., \& Febriamansyah, R. (2008). Kearifan lokal dan pemanfaatan dan pelestarian sumberdaya pesisir. Jurnal Agribisnis Kerakyatan, 1, 69-85. 